\title{
Effect of some Amino Acids and Yeast on Root-knot Disease on Tomato Plants
}

\author{
El-Nuby A. S. M. \\ Plant Protect. Dept., Desert Res. Center, Cairo, Egypt \\ Corresponding author email: ahmedelnuby.drc@gmail.com
}

\begin{abstract}
Three amino acids (AAs) viz. glycine, L-proline and L- tryptophan plus yeast fungus, Saccharomyces cerevisiae, were tested against root knot disease, RKD, caused by root-knot nematode, Meloidogyne incognita on tomato cv. Super Strain-B. All AAs and yeast showed significant reduction in the number of galls, developmental stages, egg masses and fecundity of the treated plants associated with corresponding positive response in plant growth characters. Tryptophan gave significantly higher response in reducing the final nematode population followed by L-proline and glycine at high concentrations compared with yeast and check plants. In most cases, the soil drench application was more effective than foliar spray in reducing nematode build-up. The inhibitory effect of all treatments on nematode reproduction was positively correlated with increasing the concentration used. Plant growth was also promoted by all treatments used. Generally, All AAs gave significant impact in suppressing the development of the nematode pathogen and sequentially reliving the disease severity. Results of this research offered environmentally safe approaches for combating rootknot disease. Further researches are needed to determine the proper doses, and concentrations of tested AAs and yeast under semi-field and field conditions. Investigations must include the impact on plant yield, before recommending them for managing root-knot disease or promoting plant growth on a wide scale.
\end{abstract}

Key words: Root-knot disease, Meloidogyne incognita, Amino acids, Yeast

\section{INTRODUCTION}

Plant parasitic nematodes (PPN) are devastating plant pathogens in Egypt and many tropical and subtropical countries. They have been viewed as one of the most important pathogen groups, causing significant damage. Annual yield loss was found to be more than $\$ 100$ billions worldwide in spite of using all the commercially available methods for nematode management (Thoden et al., 2011 and Coyne et al., 2018). This loss has been mediated by fluctuation in the global temperatures resulting from climatic changes, favoring PPN population in soil either by affecting their life cycle or altering the host machinery, tolerance, and facilitating the infection process to take place (Somasekhar and Prasad, 2011). Root-knot nematodes (RKNs), Meloidogyne spp., are considered the most yield-limiting group of PPN that cause root-knot disease (RKD). They are widespread all over the world and have a broad host range as they easily reproduce in/on roots of over 3,000 plant species (Abad et al., 2003 and Jones et al., 2013) causing high levels of economic loss in a multitude 
of agricultural crops worldwide. Meloidogyne represents the most polyphagous genus of PPN. About 100 species were recognized under this genus. The major species are $M$. arenaria, $M$. hapla, $M$. incognita and $M$. javanica. Their attacks affect the productivity by reducing the amount and the caliber of the fruits and causing severe agricultural losses (Kiewnick \& Sikora, 2006; Ibrahim et al., 2010; Elling, 2013 and Tranier et al., 2014).

Due to skyrocketed world population, it is very challenging to maintain the standard and productivity of food supplies for the entire population. It has been recently reported that, productivity of the tomato crop has dwindled worldwide, due to myriad diseases caused by pests and pathogens, such as phytoparasitic nematodes (Afifah et al., 2019). Chemical control is widely used as it is rapid and easy tool for controlling pests. Nematicides also are the primary methods for controlling nematodes. Currently, the negative effects of nematicides and their hazards to living organisms including their risks to air, water, non-target organisms and applicators are being noticeable. Consequently their use was restricted in many countries (Zhang et al., 2010 and Fosu-Nyarko \& Jones, 2015). Thus, there is a need to develop alternative control measures that eco-friendly to manage PPN. Environmentally benign measures appear to be a better solution for nematode management, mainly using antagonistic microorganisms and/or safety biochemicals as well as resistance genotypes to suppress or combat different pathogens and pests infecting crops (ElNuby, 2014; El-Nuby\& Bayomi, 2019; Hajihassani et al., 2019; Montasser et al., 2019 and Xiang et al., 2018). Recently, the use of antioxidants, vitamins, biotic and abiotic inducers, growth hormones, seaweeds and algae and plant extracts has been increased to manage PPNs and other plant pathogens (Afia \& El-Nuby, 2016; Alam \& El-Nuby 2019; El-Nuby, 2014; El-Nuby \& Alam, 2020 and El-Nuby et al., 2020).

Application of AAs has been reported to affect PPN. It was found that AAs obviously diminished developing of nematode females in their host (Blümel et al., 2018). Previous studies have reported that some AA can act as nematicides, due to chemotherapeutic effects on plants or direct effects on nematodes (Osman, 1993; Crow et al., 2009 and Maareg et al., 2014). Also they can act as resistances inducers against root-knot nematode (El-Nuby, 2014).

Using yeast fungus to control plant parasitic nematodes was previously examined (Karajeh, 2013). Saccharomyces cerevisiae is considered a promising yeast fungus for enhancing plant growth. In the last decades $S$. cerevisiae became effective fertilizers and minimized the use of chemicals as it is safe for human and environment (Omran, 2000). Potential use of yeast fungi as biocontrol agents of soil-borne plant pathogens and plant growth promoters was investigated (El-Tarabily, 2004; Ismail et al., 2005a,b and Youssef \& El-Nagdi, 2018). The yeast, S. cerevisiae, reduced infection of M. incognita on Egyptian henbane, Hyoscyamus muticus, and increased its growth (Youssef \& Soliman 1997). Hamouda et al. (2019) found that S. cerevisiae suppressed the nematode criteria in roots and soil of $M$. incognita infecting banana roots and also enhanced its growth. Spraying tomato plants with yeast was increased plant growth, chlorophyll in leaf tissues, NPK uptake and increased pod setting as well as total yield, average fruit weight and total solid salts (El-Ghamriny et al., 1999). The aims of the current research were evaluating certain amino acids viz., Ltryptophan, glycine and L-proline (at different concentrations) applied as pray and drench applications and brewer's yeast (S. cerevisiae) in suppressing reproduction of $M$. incognita under greenhouse conditions. 


\section{MATERIALS AND METHODS}

\section{Pathogen inoculum}

The $M$. incognita pure culture, previously identified, was originally obtained from infected tomato roots containing egg masses growing in greenhouse. Seedlings of tomato cv. Super Strain-B grown in $20 \mathrm{~cm}$ clay pots filled with sterilized soil (3 sand: 1 clay v/v) were inoculated with single egg mass of $M$. incognita. Five weeks later the plants were checked for the presence egg masses. Egg masses were incubated in tap water to help hatching. Further inoculation by the second stage juveniles for tomato seedlings was done to be a continuous source for $M$. incognita that used in this study.

\section{Greenhouse experiments}

To study the effect of the tested AAs and yeast on maturity and fecundity of RKN, four weeks old seedlings of susceptible tomato cv. Super Strain-B were transplanted in $15 \mathrm{~cm}$ - diameter clay pots filled with about $1 \mathrm{~kg}$ sterilized soil, each pot contained one seedling. The experiment was conducted at $35 \pm 5^{\circ} \mathrm{C}$ in green house. Ten days later, seedlings were inoculated with approximately 1500 freshly hatched juveniles (J2) of $M$. incognita per plant. Seven days after inoculation the plants were divided into two groups; the first which treated with AA viz., glycine, L-proline and Ltryptophan as foliar spray 3 times (ten days interval) with $50 \mathrm{ml}$ of each AAs at concentrations of 250,500 and $1000 \mathrm{ppm}$ in distilled water. The second group was treated with AAs as soil drench 3 times (ten days interval) with $150 \mathrm{ml}$ of each AA at same concentrations. For yeast application, dry active bread yeast (S. cerevisiae) was dissolved in warm tap water $\left(\approx 35^{\circ} \mathrm{C}\right)$ at $1,2.5$ and $5 \mathrm{~g} /$ liter to form a suspension and then a weight of sucrose $(5 \mathrm{~g})$ was added to activate the yeast. The mixture was stirred until fully homogenized, then kept for 3 hours at room temperature and placed in fridge until used on the same day. One week post to the nematode inoculation the yeast suspension was poured into the rhizospheric zone of each seedling. Applications were repeated 10 and 20 days later. Five replicates were used for each treatment and control pots. Control pots were drenched with tap water only. For estimating the disease progress, 50 days later; nematode galls, developmental stages and egg masses were counted in stained roots with lactophenol and acid fuchsin (Franklin and Goodey, 1959). Number of eggs per egg mass was counted by picking 10 egg masses and the eggs were counted inside each egg mass separately then the mean number of eggs/single egg mass was calculated. Total eggs/root system were also calculated by multiplying the mean number of eggs/ one egg mass by number of egg masses/root system for each replicate. The final population (Pf) that represents the summation of egg masses+ immature stages+ total eggs was calculated. The rates of nematode reproduction $(\mathrm{RR})$ were calculated by dividing the nematode final population $(\mathrm{Pf})$ by the initial population $(\mathrm{Pi})$. Growth parameters of tomato including lengths of root and shoot portion were measured, also shoot and root fresh and dry weights were recorded.

\section{Statistical Analysis}

Experiments were designed by randomized complete block design (RCBD) with five replications. All the data were analyzed by ANOVA (using JMP program from SAS 
version 7.0.1) and significant differences among the means were partitioned by least significant difference (LSD) at $P=0.05$.

\section{RESULTS}

\section{Effect of amino acids on reproduction of $M$. incognita infecting tomato plants and their impact on plant growth}

Data of table (1) revealed that all treatments, amino acids, suppressed $M$. incognita galls, egg masses, fecundity as well as nematode reproduction. The effect of AAs in relation to various nematode parameters in the treated plants was found to be statistically significant compared to untreated plants. From the data presented in table (1) drench applications were obviously better than spray one in suppressing of nematode development and reproduction. Also the effect of different treatment was positively correlated with increasing their concentrations. The control treatment recorded the highest significant number (569.7) of galls of $M$.incognita. The highest reductions $(89.8 \& 88.5 \%)$ in gall numbers were achieved by drenching proline and tryptophan at $1000 \mathrm{ppm}$, respectively, Glycine at the same concentration passed the lower reduction percentage in galls (52.4\%). Developmental stage and egg masses numbers were found to track the galls behavior in response to application of amino acid. Number of eggs per egg mass, was decreased at all treatments. The highest suppression was achieved by soil addition of highest power of tryptophan (82.6\%). and spray addition of the same treatment $(71.5 \%)$ succeeded by drenching proline at $1000 \mathrm{ppm}(61.6 \%)$, while the glycine at the same concentration hardly achieved $(32.3 \%)$. Glycine recorded reduction near to $32.3 \%$ in nematode fecundity.

Total final population (TP) was sharply decreased by the highest concentration of tryptophan soil addition (89.1\%) followed by proline in the same power and application mode (96.8\%). Drenching Tryptophan at $500 \mathrm{ppm}$ recorded $93.5 \%$ reduction in TP. Glycine achieved $84.2 \% \mathrm{R}$ in TP when supplied to tomatoes at 1000 ppm as soil drench.

The impact of amino acids on tomato growth was positive in general (Table 2). Root length increased in all treatments but differently, as the highest progress was observed with glycine, tryptophan and proline (31.54, 30.04 and 24.07, respectively). Root weight was also improved after treating with AAs. Drenching tryptophan at the highest concentration possessed the maximum weight $(10.7 \mathrm{~g})$, followed by the third concentration of drenched glycine $(9.42 \mathrm{~g})$ and also the soil addition of proline 1000 ppm (9.28g). Shoot length of tomato plants was enhanced with AA addition, drenched proline (1000 ppm) caused maximum enhancement of shoot length succeeded by both tryptophan and glycine at the highest concentration. All amino acid treatments increased shoot weight of tomatoes, tryptophan and glycine followed by proline recording the maximum percentage of increase (40.43, 40.21 and $37.61 \%$, respectively). 
Table 1. Effect of some amino acids on reproduction of Meloidogyne incognita in treated tomato plants.

\begin{tabular}{|c|c|c|c|c|c|c|c|c|c|c|c|c|}
\hline Treatments & Galls & $\%$ Red. & $\begin{array}{c}\text { Develop. } \\
\text { Stages }\end{array}$ & \% Red. & $\begin{array}{c}\text { Egg } \\
\text { masses }\end{array}$ & \% Red. & $\begin{array}{c}\text { Eggs/egg } \\
\text { mass }\end{array}$ & \% Red. & Total Eggs & $\begin{array}{c}\text { Total } \\
\text { Population }\end{array}$ & $\%$ Red. & $\mathbf{R R}$ \\
\hline Glycine D at 250 ppm & 303.0 & 46.8 & 339.3 & 47.5 & 130.3 & 53.9 & 308.0 & 27.1 & 40149.0 & 40618.7 & 66.3 & 27.1 \\
\hline Glycine $S$ at 250 ppm & 424.0 & 25.6 & 518.7 & 19.8 & 161.0 & 43.0 & 367.3 & 13.1 & 59155.7 & 59835.3 & 50.3 & 39.9 \\
\hline Glycine D at 500 ppm & 142.0 & 75.1 & 199.7 & 69.1 & 101.3 & 64.2 & 297.3 & 29.7 & 30117.3 & 30418.3 & 74.7 & 20.3 \\
\hline Glycine $S$ at 500 ppm & 212.0 & 62.8 & 324.0 & 49.9 & 135.7 & 52.0 & 331.0 & 21.7 & 44893.3 & 45353.0 & 62.3 & 30.2 \\
\hline Glycine D at 1000 ppm & 271.3 & 52.4 & 381.0 & 41.1 & 65.0 & 77.0 & 286.0 & 32.3 & 18589.3 & 19035.3 & 84.2 & 12.7 \\
\hline Glycine $S$ at 1000 ppm & 328.8 & 42.3 & 426.8 & 34.0 & 109.0 & 61.4 & 298.3 & 29.4 & 32488.0 & 33023.7 & 72.6 & 22.0 \\
\hline Proline D at 250 ppm & 187.7 & 67.1 & 232.7 & 64.0 & 72.0 & 74.5 & 232.3 & 45.0 & 16760.0 & 17064.7 & 85.8 & 11.4 \\
\hline Proline $S$ at 250 ppm & 269.3 & 52.7 & 307.7 & 52.4 & 145.3 & 48.6 & 365.3 & 13.6 & 53104.0 & 53557.0 & 55.5 & 35.7 \\
\hline Proline D at 500 ppm & 176.7 & 69.0 & 200.0 & 69.1 & 58.0 & 79.5 & 216.0 & 48.9 & 12542.7 & 12800.7 & 89.4 & 8.5 \\
\hline Proline $S$ at 500 ppm & 225.7 & 60.4 & 280.0 & 56.7 & 128.0 & 54.7 & 321.3 & 24.0 & 41132.0 & 41540.0 & 65.5 & 27.7 \\
\hline Proline D at 1000 ppm & 58.3 & 89.8 & 113.3 & 82.5 & 23.0 & 91.9 & 162.3 & 61.6 & 3730.0 & 3866.3 & 96.8 & 2.6 \\
\hline Proline $S$ at 1000 ppm & 184.0 & 67.7 & 254.0 & 60.7 & 106.3 & 62.4 & 271.0 & 35.9 & 28789.0 & 29149.3 & 75.8 & 19.4 \\
\hline Tryptophan D 250 ppm & 163.7 & 71.3 & 231.3 & 64.2 & 59.3 & 79.0 & 261.7 & 38.1 & 15555.3 & 15846.0 & 86.8 & 10.6 \\
\hline Tryptophan S at $250 \mathrm{ppm}$ & 237.7 & 58.3 & 322.7 & 50.1 & 177.3 & 37.3 & 290.3 & 31.3 & 51495.3 & 51995.3 & 56.8 & 34.7 \\
\hline Tryptophan D at 500 ppm & 116.0 & 79.6 & 158.0 & 75.6 & 37.3 & 86.8 & 205.7 & 51.3 & 7673.3 & 7868.7 & 93.5 & 5.2 \\
\hline Tryptophan S at 500 ppm & 316.3 & 44.5 & 367.0 & 43.2 & 161.0 & 43.0 & 251.0 & 40.6 & 40415.0 & 40943.0 & 66.0 & 27.3 \\
\hline Tryptophan D at 1000 ppm & 65.7 & 88.5 & 126.0 & 80.5 & 29.0 & 89.7 & 73.3 & 82.6 & 2125.3 & 2280.3 & 98.1 & 1.5 \\
\hline Tryptophan S at 1000 ppm & 163.7 & 71.3 & 229.3 & 64.5 & 156.0 & 44.8 & 120.3 & 71.5 & 18762.0 & 19147.3 & 84.1 & 12.8 \\
\hline Control & 569.7 & 0.0 & 646.3 & 0.0 & 282.7 & 0.0 & 422.7 & 0.0 & 119465.0 & 120394.0 & 0.0 & 80.3 \\
\hline LSD $5 \%$ & 7.292 & - & 10.402 & - & 2.183 & - & 4.373 & - & 725.16 & 726.55 & - & - \\
\hline
\end{tabular}

$\mathrm{D}=$ Drench, $\mathrm{S}=$ Spray, $\mathrm{RR}=$ Rate of nematode reproduction $\left(\mathrm{Pf}=\right.$ final population/Pi= initial population- $\left.1500 \mathrm{~J}_{2^{-}}\right)$, \% Red.= reduction percent 


\section{Effect of yeast on reproduction of $M$. incognita infecting tomato plants and its effect on plant growth}

Yeast was diminished the gall relatively similar to high concentration of glycine recording $53.1 \%$. The reduction achieved with yeast varied between 24.8 to $73.2 \%$ in 5 and $1 \mathrm{~g} /$ plant, respectively (Table 3 ). The rate of build up or rate of nematode reproduction (RR) was similarly behaved as TP; tryptophan at high power possessed the top rank because the nematode only multiplied 1.5 folds on plant treated with it succeeded by proline at the same power. Whereas, glycine supported proper multiplication of nematode (12.7 folds) compared with 80.3 folds in check plants.Yeast was moderately suppressed the reproduction of nematodes by $21.5,46.4$ and 60.4 for 5, 2.5 and $1 \mathrm{~g} /$ plant, respectively. The nematode fecundity was depressed $(35.3 \%)$ by yeast. In general yeast at these concentrations was less effective than amino acids, in reducing $M$. incognita reproduction.

Treating nematode infected-tomato plants with the $S$. cerevisiae had a promotion effect on plant growth. Yeast at $5 \mathrm{~g} / \mathrm{l}$ resulted in the highest significant increase in plant growth compared with other concentrations 2.5 and $1 \mathrm{~g} / \mathrm{l}$. The beneficial effects were correlated with the concentrations used. Also, the highest shoot weight was achieved with $5 \mathrm{~g} / \mathrm{l}$ of yeast compared with AAs and yeast treatments as well as noninoculated check (Table 4). The untreated plants gave the lowest growth parameters.

\section{DISCUSSION}

Recently many researchers were focusing on employing the antagonistic microorganisms and ecofriendly materials to control or suppress phytoparasitic nematodes, (Montasser et al., 2012; El-Nuby, 2014; Viggiano et al., 2015; Thakur \& Walia, 2016 and El-Qurashi et al., 2019). One of the environmentally safe chemicals is amino acids that used in general as growth improvers. The antinematodeal effect of various AAs was previously stated; DL-methionine was able to reduce the galls formed by $M$. incognita and females of both Heterodera avenae and Globodera rostochiensis under greenhouse conditions (Prasad \& Webster, 1967 and Evans \& Trudgill, 1971). Applying AAs on turf grasses diminished the field populations of $B$. longicaudatus and Mesocriconema ornatum (Crow et al., 2009). The activity of AAs towards phytonematodes varied according to the type of AAs and nematode genus. Various AAs drenched to soils as antimetabolites against nematodes such as DLaminobutyric acid, DL-methionine, DL- and L-proline reduced phytonematodes damage (Prasad \& Webster, 1967; Tsai \& Van Gundy, 1988; El-Nuby, 2014).Other AAs viz., DL-serine and DL-alanine significantly reduced the development of $M$. incognita (Prasad and Setty, 1974). Amdadul Hoque et al. (2014) reported that that all six AAs suppressed $M$. javanica gall indices, number of mature females, egg masses and immature stages inside roots of tomato plants. DL-phenylalanine gave significantly higher suppression effects in vitro and in vivo followed by L-proline.

Results of this study showed the adverse impact of L- tryptophan on RKN, which were in agreement with previous reports; Rutherford and Croll (1979) stated that, Dor L-tryptophan reduced total activity and influenced neither orientation nor the ability of thermally acclimatized of Caenorhabditis elegans individuals to remain at their eccritic temperature (as nematode are ectothermic animal, in which body heat derived largely from the environment, at eccritic temperature nematode becomes active and in optimal metabolic performance). 
Table 2. Effect of some amino acids on growth parameters of tomato plants infected by Meloidogyne incognita.

\begin{tabular}{|c|c|c|c|c|c|c|c|c|c|c|}
\hline Treatments & $\begin{array}{c}\text { Root } \\
\text { length } \\
(\mathbf{c m})\end{array}$ & $\%$ Inc. & $\begin{array}{c}\text { Root } \\
\text { weight } \\
\text { (g) }\end{array}$ & \%Inc. & $\begin{array}{l}\text { Shoot } \\
\text { length } \\
(\mathrm{cm})\end{array}$ & \%Inc. & $\begin{array}{c}\text { Fresh } \\
\text { shoot } \\
\text { weight (g) }\end{array}$ & \%Inc. & $\begin{array}{c}\text { Dry } \\
\text { shoot } \\
\text { weight }(g)\end{array}$ & \%Inc. \\
\hline Glycine D at 250 ppm & 27.00 & 21.08 & 5.13 & 64.32 & 30.00 & 2.28 & 23.17 & 9.60 & 4.09 & 18.08 \\
\hline Glycine $S$ at 250 ppm & 23.00 & 3.14 & 3.14 & 0.64 & 31.67 & 7.97 & 22.77 & 7.69 & 3.77 & 9.13 \\
\hline Glycine D at 500 ppm & 27.33 & 22.57 & 6.75 & 116.45 & 33.00 & 12.51 & 26.56 & 25.62 & 4.82 & 38.61 \\
\hline Glycine S at 500 ppm & 27.33 & 22.57 & 3.21 & 2.78 & 32.67 & 11.38 & 22.89 & 8.26 & 4.24 & 22.32 \\
\hline Glycine D at 1000 ppm & 29.33 & 31.54 & 9.42 & 202.03 & 39.00 & 32.97 & 29.64 & 40.21 & 4.94 & 42.00 \\
\hline Glycine $S$ at 1000 ppm & 28.00 & 25.56 & 5.57 & 78.42 & 38.33 & 30.70 & 23.10 & 9.29 & 4.23 & 22.13 \\
\hline Proline D at 250 ppm & 24.00 & 7.62 & 5.20 & 66.67 & 38.33 & 30.70 & 24.19 & 14.41 & 3.56 & 3.11 \\
\hline Proline $S$ at 250 ppm & 22.33 & 0.15 & 4.00 & 28.31 & 29.67 & 1.15 & 21.43 & 1.39 & 3.98 & 14.97 \\
\hline Proline D at 500 ppm & 27.33 & 22.57 & 5.39 & 72.76 & 40.00 & 36.38 & 27.35 & 29.36 & 4.62 & 33.05 \\
\hline Proline $S$ at 500 ppm & 23.67 & 6.13 & 4.77 & 52.88 & 31.67 & 7.97 & 26.87 & 27.12 & 4.33 & 24.86 \\
\hline Proline D at $1000 \mathrm{ppm}$ & 27.67 & 24.07 & 9.28 & 197.44 & 42.00 & 43.20 & 29.09 & 37.61 & 5.34 & 53.48 \\
\hline Proline S at 1000 ppm & 24.00 & 7.62 & 7.44 & 138.46 & 37.00 & 26.15 & 29.10 & 37.65 & 4.40 & 26.93 \\
\hline Tryptophan D 250 ppm & 23.33 & 4.63 & 6.41 & 105.56 & 37.67 & 28.42 & 28.18 & 33.29 & 3.99 & 15.25 \\
\hline Tryptophan $S$ at $250 \mathrm{ppm}$ & 22.67 & 1.64 & 3.18 & 1.92 & 33.67 & 14.79 & 21.53 & 1.84 & 3.51 & 1.79 \\
\hline Tryptophan D at $500 \mathrm{ppm}$ & 29.00 & 30.04 & 6.75 & 116.24 & 38.67 & 31.83 & 29.41 & 39.10 & 4.37 & 25.89 \\
\hline Tryptophan S at 500 ppm & 23.00 & 3.14 & 5.22 & 67.41 & 34.67 & 18.20 & 21.90 & 3.60 & 3.57 & 3.48 \\
\hline Tryptophan D at 1000 ppm & 29.00 & 30.04 & 10.07 & 222.76 & 39.00 & 32.97 & 29.75 & 40.73 & 4.70 & 35.31 \\
\hline Tryptophan S at 1000 ppm & 25.67 & 15.10 & 6.14 & 96.69 & 38.33 & 30.70 & 22.33 & 5.61 & 3.96 & 14.41 \\
\hline Control & 22.33 & 0.00 & 3.12 & 0.00 & 29.33 & 0.00 & 21.14 & 0.00 & 3.45 & 0.00 \\
\hline LSD 5\% & 0.933 & - & 0.427 & - & 1.815 & - & 1.106 & - & 0.229 & - \\
\hline
\end{tabular}

$\mathrm{D}=$ Drench, $\mathrm{S}=$ Spray, Inc.\%= increment percent 
Table 3. Effect of Saccharomyces cerevisiae on the development and reproduction of Meloidogyne incognita in treated tomato plants

\begin{tabular}{|c|c|c|c|c|c|c|c|c|c|c|c|c|}
\hline Treatments & Galls & $\%$ Red. & $\begin{array}{c}\text { Develop. } \\
\text { Stages }\end{array}$ & $\%$ Red. & $\begin{array}{c}\text { Egg } \\
\text { masses }\end{array}$ & \%Red. & $\begin{array}{c}\text { Eggs/egg } \\
\text { mass }\end{array}$ & $\%$ Red. & $\begin{array}{l}\text { Total } \\
\text { Eggs }\end{array}$ & $\begin{array}{c}\text { Total } \\
\text { population }\end{array}$ & $\%$ Red. & $\mathbf{R R}$ \\
\hline Yeast $5 \mathrm{~g} / 1$ & 267.3 & 53.1 & 309.0 & 52.2 & 116.0 & 59.0 & 274.3 & 35.1 & 31816.3 & 32241.3 & 73.2 & 21.5 \\
\hline Yeast $2.5 \mathrm{~g} / 1$ & 365.0 & 35.9 & 403.0 & 37.7 & 218.0 & 22.9 & 316.3 & 25.2 & 68974.7 & 69595.7 & 42.2 & 46.4 \\
\hline Yeast $1 \mathrm{~g} / \mathrm{l}$ & 420.7 & 26.2 & 530.7 & 17.9 & 243.7 & 13.8 & 368.7 & 12.8 & 89826.0 & 90600.3 & 24.8 & 60.4 \\
\hline Control & 569.7 & 0.0 & 646.3 & 0.0 & 282.7 & 0.0 & 422.7 & 0.0 & 119465.0 & 120394.0 & 0.0 & 80.3 \\
\hline LSD $5 \%$ & 23.08 & - & 25.02 & - & 7.30 & - & 11.85 & - & 3665.4 & 3665.9 & - & - \\
\hline
\end{tabular}

$\mathrm{RR}=$ Rate of nematode reproduction $=\left(\right.$ final population/initial population- $\left.1500 \mathrm{~J}_{2^{-}}\right), \% \mathrm{Red} .=$ reduction percent

Table 4. Effect of Saccharomyces cerevisiae application on tomato growth infected with Meloidogyne incognita

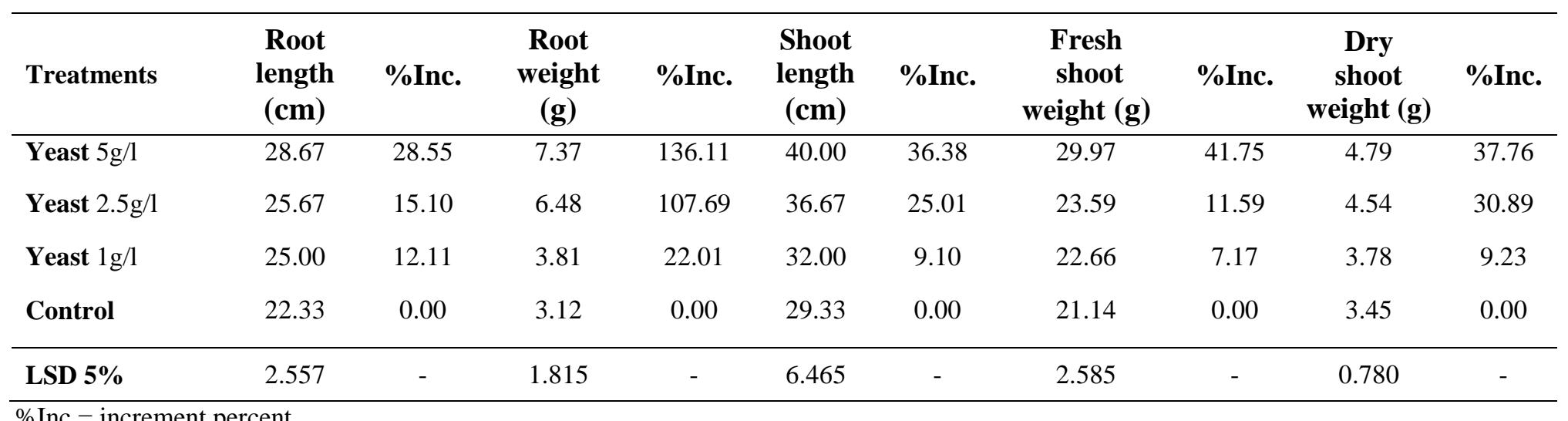

\%Inc.= increment percent 
Tryptophan has a negative influence on cyst nematode syncytium or may be toxic to nematodes (Betka et al., 1991). Osman (1993) found that AAs and ascorbic acid diminished development and number of deposited eggs of $M$. javanica. Other researches supported this finding (Arrigoni et al., 1979 and AL-Sayed et al., 1986). Accumulation of different AAs and enzyme activities in nematode- inoculated plants play essential and vital role in nematode hatching, survival and gall formation as reported by many researchers (Mohanty et al., 1997; Brenner et al., 1998; Perelman \& Lu, 2000 and Mohanty et al., 2001). The exact mechanism of nematode suppression by these AAs has not been fully understood, but D-AAs are believed to concentrate near root tips or nematode feeding sites, consequently obstructing metabolic pathways in plant or nematode (Prasad \& Webster, 1967). It is assumed that AAs like DL-3aminobutyric acid decreased the attractiveness of tomato roots to $\mathrm{RKN}$, roots acquired some rigidity that dwindle invasion of the larvae, or synthesis some compounds that may repress nematode or retard establishment and development of giant cells in roots. (Oka et al., 1999 and El-Nuby, 2014). Some studies proved that AAs have an impact on nematode lifespan; Edwards et al. (2015) found that all AAs except phenylalanine and aspartate extended lifespan at different concentrations with serine and proline showing the largest effects while tryptophan-mediated lifespan extension. Also therrmotolerance was enhanced by proline or tryptophan addition. As a stress response, some substances are synthesized by the plant in response to adverse or stress conditions, including osmo-regulator or protector AAs such as proline, which may increase stress tolerance to the plant (Hassan et al., 1994 and Shulaev et al., 2008). Also, AAs may play a role in the resistance mechanism in the host against root-knot disease. This assumption may be confirmed by the results of Sauh \& Mohonty (1987) and Zocheo et al. (1988). Besides, AAs may have a repellent action to $M$. javanica larvae. It was also mentioned that free AAs increased by increasing plant resistance (Meon, 1978). Some researchers suggested that antimetabolites such as some DL- AAs might be used as nematicides. (Oteifa \& ELGindi, 1961; Prasad \& Webster, 1967; Evans \& Trudgill, 1971 and Sharma \& Tiagi, 1984). Similarly, enhancing resistance toward some diseases in certain hosts treated with some AAs which are generally DL- forms was documented (Zentmyerm et al., 1962). Different finding by Meon (1978) was reported, as he found that L-proline increased females of $M$. javanica. The significant inhibition to $\mathrm{RKN}$ by the AAs in this study may be due to not only their type but also for the repeated application and also the concentration used.

Results obtained in the current investigation showed inhibition of RKN reproduction by yeast application, also the efficacy of yeast was positively correlated with increasing concentration of $S$. cerevisiae. This finding is supported by previous results of Karajeh, (2013) he observed remarkable reduction in M. javanica-galls on cucumber roots and accordingly suppressed nematode multiplication after application of yeast to soil, besides the high concentration $10 \mathrm{~g} / \mathrm{liter}$ are more effective than using 5 grams. Another study revealed that $S$. cerevisiae inhibited $M$. incognita population in Egyptian henbane (Youssef and Soliman, 1997). Another investigation confirmed the suppressive impact of $S$. cerevisiae in reducing nematode population in jasmine (Ismail et al., 2005). Also commercial product of $S$. cerevisiae suppressed RKN galls and soil population of infected squash (Noweer and Hasabo, 2005). Recently, Osman et al. (2020) found significant reduction in the $M$. javanica population in peanut plants under field conditions. The suppressive effect of yeast against root-knot nematode may due to induction of plant resistance and promotion of plant vigor. It was suggested that, the ability of $S$. cerevisiae to utilize carbohydrates and produce ethanol 
and carbon dioxide which are nematotoxic compounds. Different mechanisms, competition for nutrients site exclusion, parasitism and induced resistance and/or make physical and chemical soil properties unsuitable for plant pathogens, of yeast bio-control activity were proposed (Ahmed et al., 1972; Alam et al., 1977; Sitaramaiah \& Singh, 1978 and Noweer \& Hasabo, 2005).Controlling soil-borne plant pathogenic fungi by $S$. cerevisiae was also reported (El-Tarabily, 2004 and Shalaby \& El-Nady, 2008).

Results revealed that amino acids (AA) tested achieved promotion in tomato growth, L-tryptophan was effective than proline and glycine, and the promotion was concentration dependent in many cases. Stimulating effect of L-tryptophan compared to another AA was early documented (Viglierchio and $\mathrm{Yu}, 1965)$. Masood and Husain (1975) observed higher plant growth with L-proline applied as soil drench, in the same experiment they found the best plant growth recorded with phenylalanine drenched to M. incognita -infected plants. Similarly, Amdadul Hoque (2014) showed significant response in plant growth characters, form the six AA tested, L-proline gave significantly higher response in the development of length of shoot and root and fresh weight of shoot and root correspondingly with lower galling incidence but phenylalanine was more growth promoter. These finding also is in accordance with results of Meon (1978), who found that L-tryptophan showed more positive effect on growth of tomato plants than L-proline, but he found no significant difference between various concentrations of AA on tomato growth. Other investigations reported the enhancement of growth and yield of many crops after exogenous treatment of L- tryptophan via directly or indirectly approach (Parvez et al., 2000: Akhtar et al., 2007 and Zahir et al., 2010). It was stated that, L-tryptophan represents a precursor of auxin biosynthesis in plants and microorganisms. The efficacy of tryptophan in plant growth might be due to increasing the availability of auxin from soil microbes, that enhanced by tryptophan addition which was absorbed by plants, another interpretation is direct absorption of tryptophan by plants which turned into auxins inside them or as results to modification in the equilibrium of rhizosphere microflora after addition of tryptophan which may affect growth and yield (Abbas, 2013). Treating tomato plants (free form nematode) with AA caused significant increase in growth and yield of tomatoes compared with untreated plants (Boras et al., 2011), they found that spray AA was better than soil addition in some growth parameters; plant length, leaf area, fruit production, ascorbic acid and organic acids in fruits. Several researches supported the stimulatory effects of yeast on different plants (Youssef and Soliman, 1997; Ismail et al., 2005; Koukounaras et al., 2013; Alali et al., 2017 and Osman et al., 2020). Akhtar and Alam (1990) found an increase in growth and yield of yeast treated- plants, also the growth promotion was correlated with nematode suppression. Karajeh, (2013) reported stimulating in cucumber vigor and yield under growth-chamber and field conditions. The growth-enhancing effect of yeast application might be due to that cytokinins production by yeast responsible for elevation production and accumulation of soluble metabolites (Muller and Leopold, 1966). It was suggested that yeast playing a role in enlarging and division of plant cells, also it have a positive impact on vegetative and yield (Nagodawithana, 1991 and Nassar et al., 2005). The growth stimulation achieved by yeast may be due to its richness in proteins, carbohydrates, nucleic acid, lipids, vitamins and different minerals (Wareing and Phillips, 1970). It can improve manganese and phosphorus uptake by the plant roots (Mekki and Ahmed, 2005). 
The superior effect on plant growth of amino acid in general vs. yeast, in current study, may due to the low concentration of yeast used. Also it might be the estimated parameters which did not include the count of flowers and subsequently the fruits criteria. Amino acid, L-glutamic, was effective than yeast in diminishing $M$. incognita infection in carnation plants (Hamza et al., 2013). Also the preparation procedure of yeast suspension may also play a role in its activity, e.g. addition of Egyptian treacleblack honey- and incubation conditions before application (Osman et al., 2020).

\section{CONCLUSION}

The application of the amino acids and yeast (S. cerevisiae) could suppress fecundity and final population of $M$. incognita on tomato. L- tryptophan was the best nematode suppressor and tomato growth promoter, other treatments also have a positive impact in combating root-knot disease in tomato and stimulating plant growth. Further extensive studies that cover the suitable application conditions (plant age, concentration, combination, repetition, etc.) for AA and yeast are needed, also to ascertain whether specific amino acids can serve as nematicides for field application. This study offers an eco-friendly nematode inhibitors as well as plant growth promoters, which are useful in reduction the environmental pollution, by decreasing the pesticide use, and optimizing the use of agricultural resources in sustainable approaches.

\section{REFERENCES}

Abad, P.; Favery, B.; Rosso, M. N. and Castagnone-Sereno, P. (2003). Root-knot nematode parasitism and host response: Molecular basis of a sophisticated interaction. Mol. Plant Pathol. 4: 217-224.

Abbas, S.H.; Sohail M.; Saleem, M., Mahmood T., Aziz, I., Qamar, M., Majeed, A. and Arif, M. (2013). Effect of L-treptophan on plant weight and pod weight in chickpea under rained conditions. Sci. Tech. Dev. 32 (4): 277-280.

Afia, A.I. and El-Nuby, A.S.M. (2016). Seaweeds as a managing approach for rootknot nematode disease. Egypt. J. Agronematol. 15 (2): 95-108.

Afifah, E.N.; Murti, R.H.; Nuringtyas, T.R. (2019). Metabolomics approach for the analysis of resistance of four tomato genotypes (Solanum lycopersicum L.) to root-knot nematodes (Meloidogyne incognita). Open Life Sci. 14: 141-149.

Ahmed, R.; Khan, A.M.; Saxena, S.K. (1972). Changes resulting from amending the soil with oil-cakes and analysis of oilcakes. Proc. $59^{\text {th }}$ Ses. Indian Sci. Cong; Calcutta, Part 3: 164 (abstract).

Akhtar, M. and Alam, M.M. (1990). Control of plant parasitic nematodes with agrowastes soil amendment. Pak. J. Nematol. 8: 5-28.

Akhtar, M.J.; Asghar, H.N.; Asif, M. and Zahir, Z.A. (2007). Growth and yield of wheat as affected by compost enriched with chemical fertilizer, L-tryptophan and rhizobacteria. Pak. J. Agri. Sci. 44(1): 136-140.

Alali, F.A.; Alabboud, M. and Alden, K.M. (2017). The effect of foliar spray of yeast extract on the vegetative growth and productivity in tomato. 3rd International conference on sustainable development, strategies and challenges with a focus on Agriculture, Natural Resources, Environment and Tourism 7-9 March 2017, Tabriz , Iran. https://www.researchgate.net/publication/316527820 
Alam, E.A. and El-Nuby, A.S.M. (2019). Phytochemical and antinematodal screening on water extracts of some plant wastes against Meloidogyne incognita. Int. J. Chem. Pharm. Sci. 10 (4):1-16.

Alam, M.M.; Siddiqui, S.A. and Khan, A. (1977). Mechanism of control of plant parasitic nematodes as a result of the application of organic amendments to the soil.3. Role of phenols and amino acids in host root. Indian J. Nematol. 7:2731.

Al-Sayed, A.A.; Montasser, S.A. and Sayed, A.A. (1986). The role of ascorbic and glutamic acids in controlling the root knot nematode Meloidogyne javanica. Egypt. J. Phytopathol.18 (2): 143-148.

Amdadul Hoque, A.K.M.; Bhuiyan, M.R.; Khan, M.A.I.; Mahmud, A. and Ahmad, M.U. (2014). Effect of AA on root-knot nematode (Meloidogyne javanica) infecting tomato plant. Arch. Phytopathol. Plant Prot. 47(16):1921-1928. http://dx.doi.org/10.1080/03235408.2013.862039

Arrigoni, O. (1979). A biological defense mechanism in plant. Pages 457-467. In: F. Lamberti and C.E. Taylor (eds.): Root-Knot Nematodes (Meloidogyne spp.): Systematics, Biology and Control. Acad. Press, London and New York, 477 pp.

Balasubramanian, M. and Myers R.F. (1971). Nutrient media for plant-parasitic nematodes: II. Amino acid requirements of Aphelenchoides sp. Exp.Parasitol. 29: $330-336$

Betka, M.; Grundler, F. and Wyss, U. (1991). Influence of changes in the nurse cell system (syncytium) on the development of the cyst nematode Heterodera schachtii: single amino acids. Phytopathology 81(1): 75-79.

Blümel, R.C.; Fischer, D.F. and Grundler, F.M.W. (2018). Effects of exogenous amino acid applications on the plant-parasitic nematode Heterodera schachtii, Nematology 20(8): 713-727.

Boras, M.; Zidan, R. and Halloum, W. (2011). Effect of amino acids on growth, production and quality of tomato in plastic greenhouses. Tishreen University Journal for Research and Scientific Studies - Biol. Sci. Ser. 33(5): 229-238.

Brenner, E.D.; Lambert K.N.; Kaloshian, I. and Williamson, V.M. (1998). Characterization of LeMir, a root-knot nematode-induced gene in tomato with an encoded product secreted from the root. Plant Physiol., 118: 237-247.

Coyne, D.L.; Cortada, L.; Dalzell, J.J.; Claudius-Cole, A.O.; Haukeland, S.; Luambano, N. and Talwana, H. (2018). Plant-parasitic nematodes and food security in sub-saharan Africa. Annu. Rev. Phytopathol.56: 381-403.

Crow, W.T.; Cuda, J.P. and Stevens, B.R. (2009). Efficacy of methionine against ectoparasitic nematodes on golf course turf. J.Nematol. 41: 217-220. DOI: 10.1163/15685411-00003169

Edwards, C.; Canfield, J.; Copes, N.; Brito, A.; Rehan, M.; Lipps, D.; Brunquell, J.; Westerheide, S.D. and Bradshaw, P.C. (2015). Mechanisms of amino acidmediated lifespan extension in Caenorhabditis elegans. BMC Genetics, (16):8, DOI 10.1186/s12863-015-0167-2

El-Ghamriny, E. A.; H. M. E. Arisha, and K. A. Nour (1999). Studies on tomato flowering, fruit set, yield and quality in summer season. 1.-spraying with Thiamine, ascorbic acid and yeast. Zagazig J. Agric. Res. (Egypt) 26 (5)13451364.

El-Nuby, A.S.M. (2014). Evaluation of some resistance inducers against the root-knot nematode. PhD Thesis, Fac. Agric., Cairo Univ. pp 297. 
El-Nuby, A.S.M. and Alam, E.A. (2020). Phytochemical and Nematicidal Activity Studies of Some Extracts of Different Plant Parts of Leucaena leucocephala against Meloidogyne incognita. Int. J. Chem. Pharm. Sci. 11 (1):1-17.

El-Nuby, A.S.M. and Bayomi, K.E.M. (2019). Evaluation of tomato inbred lines for resistance to root-gall nematode Egypt. J. Desert Res., 69, Special Issue, 3346. The $1^{\text {st }}$ Conference of Plant Prot. Sci. Appl. Sust. Develop. Desert Areas "Effect of Climate Change on Plant Pests and Biodiversity in Desert Environment" 19-20 October, 2019, Cairo-Egypt.

El-Nuby, A.S.M.; Montasser, S.A. and El-Khadrawy IA (2020). Control of root-knot nematodes using wild plants colonized Sinai, Egypt. Pak. J. Nematol. 38(1): 67-80.

El-Qurashi, M.A.; Aida M.I. El-Zawahry; K.M. H. Abd-El-Moneem and M.I. Hassan (2019). Occurrence, population density and biological control of root-knot nematode, Meloidogyne javanica infecting pomegranate orchards in Assiut governorate, Egypt. Assiut J. Agric. Sci. 50. (2):176-189.

El-Tarabily, K.A. (2004). Suppression of Rhizoctonia solani diseases of sugar beet by antagonistic and plant growth promoting yeasts. J. Appl. Microbiol. 96:69-75.

Evans, K. and Trudgill, D.L. (1971). Effect of amino acids on the reproduction of Heterodera rostochiensis. Nematologica 17, 495-500.

Franklin, M.T. and J.B. Goodey (1959). A cotton-blue lactophenol technique for counting plant parasitic nematodes. J. Helminthol. 23: 175-178.

Fosu-Nyarko, J. and Jones, M.G.K. (2015). Application of biotechnology for nematode control in crop plants. Adv. Bot. Res. 73:339-76

Gálvez, A.; del Amor, F.M.; Ros, C. and López-Marín, J. (2019). New traits to identify physiological responses induced by different rootstocks after rootknot nematode inoculation (Meloidogyne incognita) in sweet pepper. Crop Prot. 119:126-133.

Gusev, N.A. and Gordon, L.kh. (1968). Possible reason for accumulation of proline in plants during drought. Fisiol. Vodoobmena Ustoich Rast. 1: 47-52 (Russian).

Hajihassani, A.; Rutter, W. B.; Schwarz, T.; Woldemeskel, M.; Ali, M. E. and Hamidi, N. (2019). Characterization of resistance to major tropical root-knot nematodes (Meloidogyne spp.) in Solanum sisymbriifolium. Phytopathology 110: 666-673

Hamouda, R.A.; Al-Saman, M.A. and El-Ansary, M.S.M. (2019). Effect of Saccharomyces cerevisiae and Spirulina platensis on suppressing root-knot nematode, Meloidogyne incognita infecting banana plants under greenhouse conditions. Egypt. J. Agronematol. 18 (2): 90 -102

Hamza, A.M.; Abd El-Kafie, O.M.; Nour El-Deen, A.H. and Abd El-Baset, M.M. (2013). Improving carnation resistance to root-knot nematode infection under greenhouse conditions J. Plant Prod., Mansoura Univ., 4 (8): 1159-1168.

Hassan, H.; Khalf-Allah, A.M.; Ibrahim, I.K.A. and Badr, H.M. (1994). Free amino acids and oxidative enzymes in infested roots of tomato genotypes resistant and susceptible to Meloidogyne incognita. Nematol. Medit. 22: 179-183.

Ibrahim, I.K.A.; Mokbel, A.A. and Handoo, Z.A. (2010) Current status of phytoparasitic nematodes and their host plants in Egypt. Nematropica 40:239262.

Ismail, A.E.; El-Nagdi, W. and Hasabo S.A. (2005a). Efficacy of some local isolates of Saccharomyces cerevisiae, Trichoderma harzianum and T. ressei as bioagents for controlling Helicotylenchus exallus and Pratylenchus zeae infecting jasmine in Egypt. Egypt J. Biol. 33:27-40 
Ismail, A.E.; El-Nagdi, W.M.A., and Hasabo, S.A. (2005b). Efficacy of some local isolates of Saccharomyces cerevisiae, Trichoderma harzianum and T. ressei as bioagents for controlling Helicotylenchus exallus and Pratylenchus zeae infecting jasmine in Egypt. Egypt. J. Phytopathol. 33: 27-40.

Jones, J.T.; Haegeman, A.; Danchin, E.G.J.; Gaur, H.S.; Helder, J. and Jones, M.G.K., et al. (2013). Top 10 plant-parasitic nematodes in molecular plant pathology. Mol. Plant Pathol., 14: 946-961.

Karajeh, M.R. (2013). Efficacy of Saccharomyces cerevisiae on controlling the rootknot nematode (Meloidogyne javanica) infection and promoting cucumber growth and yield under laboratory and field conditions. Arch. Phytopathol. Plant Prot. 46(20): 2492-2500.

Kiewnick, S.; and Sikora, R.A. (2006). Biological control of the root-knot nematode Meloidogyne incognita by Paecilomyces lilacinus Strain 251. Biol. Control 38: 179-187.

Koukounaras, A., Tsouvaltzis, P. and Siomos, A.S. (2013). Effect of root and foliar application of AA on the growth and yield of greenhouse tomato in different fertilization levels. J. Food Agric. Environ. 11(2):644-648.

Maareg, M.F.; El-Gindi, A.Y.; Gohar, I.M.A. and Agami, K.M. (2014). An ecofriendly root- knot nematode pest management strategy on sugarbeet using some amino and organic acids. Egypt. J. Agronematol. 13(1):146-159.

Mekki, B.B. and Ahmed, A.G. (2005). Growth, yield and seed quality of soybean (Glycine max L.) as affected by organic, biofertilizer and yeast application. Res. J. Agric. Biol. Sci. 1:320-324.

Meon, S. (1978). The physiology of tomato infected with root-knot nematode, Meloidogyne javanica. Ph.D. thesis, Waite Agric. Res. Inst., Univ. Adelaide, South Australia. pp 171.

Mohanty, K.C., Dash, L. and Swain, S.C. (2001). Effect of Meloidogyne incognita on nodulation and root biochemistry in French bean. Indian Ann. Plant Prot. Sci. 9:81-86.

Mohanty, K.C.; Mohanty P.K.; Pradhan T. (1997). Effect of Meloidogyne incognita on root biochemistry and functioning of nodules in green gram. Indian $\mathrm{J}$. Nematol. 27:1-5.

Montasser, S.A.; Abd El- Wahab, A.E., Abd-Elgawad, M.M.M., Abd-El-Khair H., Koura F.F.H. and Hammam, M.M.A. (2012). Effects of some fungi and bacteria as bio-control agents against citrus nematode Tylenchulus Semipenetrans Cobb. J. Appl. Sci. Res. 8(11): 5436-5444.

Montasser, S.A; El-Nuby, A.S.M. and El-Khadrawy, I.A.M. (2019). Response of certain vegetable genotypes to the root knot nematode, Meloidogyne incognita. J. Plant Prot. Pathol. Mansoura Univ.10 (3): 177-186.

Muller, K. and Leopold, A.C. (1966). Correlative aging and transport of p32 in corn leaves under the influence of kinetin. Planta. 68:167-185.

Nagodawithana, W.T. (1991). Yeast technology. Universal foods cooperation Milwauke, Wisconsin.New York: Van Nostrand.

Nassar, A.H.; EI-Tarabily, K.A. and Sivasithamparam, K. (2005). Promotion of plant growth by an auxin producing isolate of the yeast Williopsis saturnus endophytic in maize (Zea mays L.) roots. Biol. Fertil. Soils 42:97-108.

Noweer, E.M. and Hasabo, S.A. (2005). Effect of different management practices for controlling root-knot nematode Meloidogyne incognita on squash. Egypt. J. Phytopathol. 33:73-81. 
Oka, Y.; Cohen, Y. and Spiegel, Y. (1999). Spiegel local and systemic induced resistance to the root- nematode in tomato by DL- $\beta$-Amino- $n$-Butyric Acid. Phytopathology 89(12):1139-1143.

Omran, Y.A. (2000). Studies on histophysiological effect of hydrogen cyanamide (Dormex) and yeast application on bud fertility, vegetative growth and yield of Roumi Red grape cultivar, Ph.D. thesis, Fac. Agric., Assiut Univ., Egypt.

Osman, G.Y. (1993). Effect of amino acids and ascorbic acid on Meloidogyne javanica Chitw. (Tylenchidae, Nematoda). Anz. Schiidlingskde., Pflanzenschutz, Umweltschutz 66: 140-142.

Osman, H.A.; Ameen, H.H.; Mohamed, M. and Elkelany, U.S. (2020). Efficacy of integrated microorganisms in controlling root-knot nematode Meloidogyne javanica infecting peanut plants under field conditions. Bull. Nat. Res. Centre 44:134.

Oteifa, B.A. and El-Gindi, D.M. (1961). Physiological studies on host-parasite relations of the root-knot nematode, Meloidogyne javanica. Plant. Dis. Reptr. (15): 928-929.

Owens, R.G. and Specht, H.M. (1966). Biochemical alterations induced in host tissues by root-knot nematodes. Contri. Boyce Thompson Inst. 23: 181-198.

Parvez, M.A.; Muhammad, F. and Ahmad, M. (2000). Effect of auxin precursor LTryptophan) on the growth and yield of tomato (Lycopersicon esculentum). Pak. J. Biol. Sci. 7(3): 1154-1155.

Perelman, D. and Lu NC. (2000). Requirements for branched chain AA and their interactions in the nematode Caenorhabditis elegans. Nematol. (2):501-506.

Prasad, K.S.K. and Setty, K.G.H. (1974). The effect of amino acids as foliar spray on root-knot nematode (Meloidogyne incognita) and tomato. Indian J Nematol. 4:88-90.

Prasad, S.K. and Webster, J.M. (1967). The effect of amino acid antimetabolites on four nematode species and their host plants. Nematologica 13: 318-323.

Rutherford, T.A. and Croll, N.A. (1979). Wave Forms of Caenorhabditis elegans in a Chemical Attractant and Repellent and in Thermal Gradients. J. Nematol.11(3): 232-240.

Sahu, R.C. and Mohanty, K.C. (1987). Free amino acids changes in the roots of blackgram infected with root-knot nematode, Meloidogyne incognita. Indian J. Nematol.17(2):155-158.

Shalaby, M.E. and El-Nady, M.F. (2008). Application of Saccharomyces cerevisiae as a biocontrol agent against Fusarium infection of sugar beet plants. Acta Biol. Szeged. 52: 271-275

Shulaev, V.; Cortes, D.; Miller, G. and Mittler, R. (2008). Metabolomics for plant stress response. Physiol. Plant 132: 199-208.

Sitaramaiah, R. and Singh, R.S. (1978). Effect of organic amendments on phenolic content of soil and plant and response of Meloidogyne javanica and its host to related compounds. Plant Soil. 50: 671-679.

Somasekhar, N. and Prasad, J.S. (2011). Plant-Nematode Interactions: Consequences of Climate Change. In Crop Stress and Its Management: Perspectives and Strategies; Springer: Cham, The Netherlands, pp. 547-564.

Thakur, S. and Walia, R.K. (2016) Potential of bacterial parasite, Pasteuria penetrans application as nursery soil treatment and seed treatment in controlling Meloidogyne graminicola infecting rice. Indian J Nematol. 46:1619. 
Thoden, T.C.; Korthals, G.W. and Termorshuizen, A.J. (2011). Organic amendments and their influences on plant-parasitic and free-living nematodes: A promising method for nematode management. Nematology 13: 133-153.

Tranier, M.S.; Gros, J.P.; Quiroz, R.D.; González, C.N.; Mateille, T. and Roussos, S. (2014). Commercial biological control agents targeted against plant-parasitic root-knot nematodes. Braz. Arch. Biol. Technol. 57 (6): 831-841.

Tsai, B.Y. and Van Gundy, S.D. (1988). Effect of DL-methionine on host response to root knot nematodes. (Abstr.) J. Nematol. 20: 661-662.

Viggiano, J.R.; Freitas, L.G. and Lopes, E.A. (2015). Pochonia chlamydosporia var. chlamydosporia (Goddard) Zare \& W. Gams for the management of lettuce infected with Meloidogyne javanica (Treub, 1885). Chilean J. Agric. Res. 75:255-258.

Viglierchio, D.R. and Yu, P.K. (1965). Plant parasitic nematodes: A new mechanism for injury of hosts, Science 147: 1301-1303.

Wareing, P.E. and Phillips, I.D.J. (1970). The control of growth and differentiation in plants. 1st ed. Oxford: Pergamon Press; p. 303.

Xiang, N.; Lawrence, K.S. and Donald, P.A. (2018). Biological control potential of plant growth-promoting rhizobacteria suppression of Meloidogyne incognita on cotton and Heterodera glycines on soybean: A review. J. Phytopathol. 166: 449-458.

Youssef, M.M.A. and Soliman, M.M. (1997). Effect of Integrated Management on Meliodogyne incognita Infecting Egyptian Henbane, Hyoscyamus muticus and on Subsequent Cowpea Plant, Proceedings of the 1st Science Conference of Agriculture Sciences, Faculty of Agriculture, Assiut University, Egypt, pp. 585-594.

Youssef, M. M. A. and El-Nagdi, Wafaa M. A. (2018).Population density of Meloidogyne incognita and eggplant growth vigour affected by sucroseactivated bread yeast (Saccharomyces cerevisiae). Pak. J. Nematol. 36 (2): 117-122.

Zacheo, G.; Molinar, S. and Pacoda, D. (1988). Hydroxyprolinerich proteins and peroxidases in tomato roots infested by root-knot nematode. Nematol. Medit. 16(2): 235-237.

Zahir, A.Z.; Yasin, H.M.; Naveed M.; Anjum, M.A. and Khalid, M. (2010). Ltryptophan application enhances the effectiveness of rhizobium inoculation for improving growth and yield of mungbean (vignaradiata (L.) Wilczek). Pak. J. Bot. 42 (3): 1771-1780.

Zentmyer, G.A.; Moje, W. and Mircetich, S.M. (1962). Ethionine as a chemotherapeutant. Phytopathology 52: 34 (abstr.)

Zhang, Y.; Luc J.E. and Crow, W.T. (2010). Evaluation of amino acids as trufgrass nematicides. J. Nematol. 42(4): 292-297. 


\section{الملخص العربي}

تأثير بعض الأحماض الأمينية و الخميرة علي مرض تعقد الجذور في نبات الطماطم

أحمد سليمان محمد محمد النوبي

$$
\text { قسم وقاية النبات - مركز بحوث الصحراء - مصر }
$$

تم دراسة تأثثر ثلاث أحماض أمينية : الجليسين - البرولين- التربتوفان بالاضافة الى الخميرة Saccharomyces cerevisiae Meloidogyne incognita

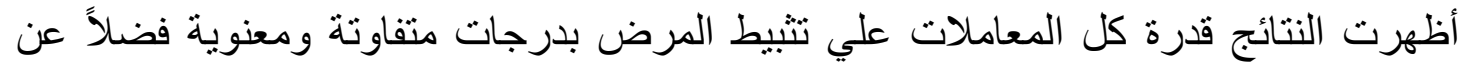
التأثير الإيجابي علي نمو النباتات. كان أفضل المعاملات هو التربتوفان تناه البرولين ثاني

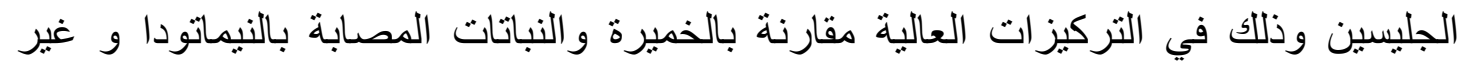
المعاملة. كانت الإضافة للتربة أفضل من الرش الورقي في معظم الأحيان في خفض التض التعداد

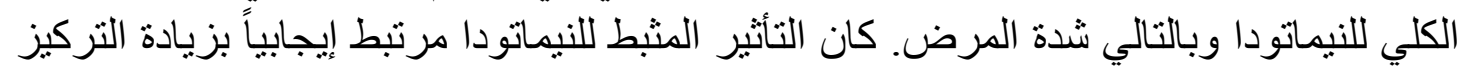

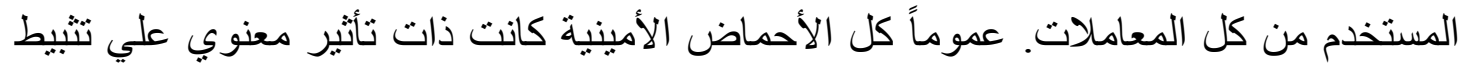

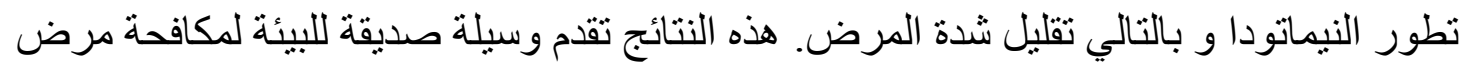

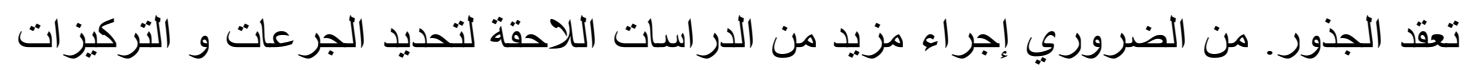

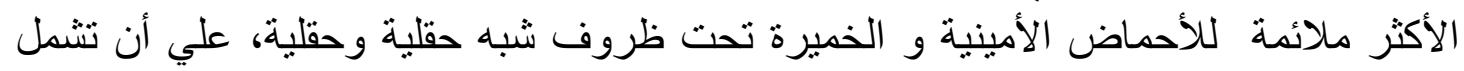
التجارب تقدير المحصول النهائي للنبات، قبل التوصية بإستخدامهم لمكافحة مرض تعقد الجذور أو تحفيز نمو النبات علي نطاق واسع. 